\title{
REGIÕES ECONÔMICAS MÍNERO-METALÚRGICAS E OS RISCOS DE DESASTRES AMBIENTAIS DAS BARRAGENS DE REJEITO NO BRASIL
}

ECONOMIC REGIONS OF MINING AND METALLURGY AND THE RISK OF ENVIRONMENTAL DISASTERS WITH TAILINGS DAMS IN BRAZIL REGIONES ECONÓMICAS MINERO-METALÚRGICAS Y LOS RIESGO DE DESASTRES AMBIENTALES CON LOS DIQUE DE RESIDUOS MINEROS EN BRASIL

\section{Maria Célia Nunes Coelho}

PhD em Geografia pela Syracuse University. Professora (aposentada) Colaboradora do Programa de Pós-graduação em Geografia da Universidade Federal do Rio de Janeiro e Pesquisadora 1D do CNPq. Av. Athos da Silveira Ramos, 274 - Cidade Universitária, Rio de Janeiro - RJ, 21044-020. E.mail:mcncoelho@gmail.com

\section{Luiz Jardim Wanderley}

Doutor em geografia pela Universidade Federal do Rio de Janeiro. Docente do Departamento de Geografia da Faculdade de Formação de Professores da Universidade do Estado do Rio de Janeiro UERJ-FFP. Rua Dr. Francisco Portela, 1470, Patronato, São Gonçalo. E.mail: luizjardim.ffp@gmail.com

\section{Tomás Coelho Garcia}

Doutor em Sociologia pelo Instituto de Estudos Sociais e Políticos (IESP). Docente de sociologia da Instituição Federal de Educação, Ciência e Tecnologia do Rio de Janeiro (IFRJ). IFRJ-Campus Paracambi. Rua Sebastião Lacerda, s/no, Centro - Paracambi - CEP: 26600-000. E.mail: tomas. garcia@ifrj.edu.br

\section{Estêvão José da Silva Barbosa}

Doutor em Geografia Física pela Universidade de São Paulo. Docente da Faculdade de Tecnologia em Geoprocessamento da Universidade Federal do Pará - UFPa Ananindeua. BR $316 \mathrm{Km}$ 7, Ananindeua - Pará.E.mail:estevaobarbos@yahoo.com.br 


\section{RESUMO}

Esse artigo diz respeito às regiões de acumulação capitalista, historicamente concebidas e continuamente construídas pelo Estado brasileiro e por empresas de mineração e metalurgia, no Sudeste e Norte do Brasil. Essas regiões se constituíram com base no caráter "desenvolvimentista" dos governos nacionais e pela existência de riquezas minerais demandadas pelo mercado internacional. O objetivo foi analisar os papéis dos governos, dos agentes estatais e das empresas no esforço de inserção do local/ regional na economia mundial, sem seguirem, entretanto, as normas das regulações ambientais, resultando na criação de "regiões de riscos ambientais" e na ocorrência de desastres. Os exemplos das regiões onde ocorreram os recentes desastres com barragens de rejeito das empresas Alunorte e da Samarco refletem como os desastres ambientais estão associados ao modo desregulado de criação de regiões econômicas mínero-metalúrgicas no Brasil.

Palavras-Chave: Riscos; Desastres Ambientais; Barragens de Rejeitos; Regiões Econômicas; Produção de Escalas.

\section{ABSTRACT}

This article analyzes the economic accumulation regions historically constructed by the Brazilian State and by mining and metallurgy companies in the Southeast and North of Brazil. These regions were founded on the development project of national governments and by the existence of mineral wealth globally demanded. The objective was to investigate the roles of governments, state agents and companies in the effort to integrate the local / regional in the world economy, without, however, following the standards of environmental regulations, resulting in the creation of "regions of environmental risks" and in the occurrence of disasters. The examples of the regions where the recent tailings dam disasters of the Alunorte and Samarco companies occurred reflect how environmental disasters are associated with the deregulated way of creating economic mining-metallurgical regions in Brazil.

Keywords: Environmental Risks; Disasters; Regions; Economic Regions; Production of Scale; Tailings Dams;

\section{RESUMEN}

Este artículo trata de las regiones de la acumulación capitalista, históricamente diseñadas y construidas por el Estado brasileiro y las empresas mineras y metalúrgicas, en el sudeste y el norte de Brasil. Estas regiones se constituyeron sobre la base del proyecto de "desarrollo" de los gobiernos nacionales y por la presencia de los recursos minerales que demanda el mercado internacional. El objetivo fue analizar el papel de los gobiernos, agentes estatales y empresas en los esfuerzos de integración local/regional en la economía global sin obedecer, sin embargo, las normas de regulaciones ambientales, lo que resulta en la creación de "zonas de riesgo ambiental" y en la ocurrencia de desastres. Los ejemplos de las regiones en las que los desastres recientes con los dique de residuos mineros de las empresas Alunorte y Samarco ocurrieron reflejan cómo los desastres ambientales están asociados con forma desregulada de la creación de regiones económicas minero-metalúrgicas en Brasil.

Palabras clave: Riesgos; Desastres Ambientales; Dique de Residuos Mineros; Regiones Económicas; Producción de Escalas. 


\section{INTRODUÇÃO}

Depois de passado mais de um ano do desastre ambiental da mineradora Samarco S.A. em Mariana/MG (ocorrido em 5 de novembro de 2015), o assunto desastre na mineração industrial ainda está a merecer reflexões mais amplas. Os recentes desastres na mineração ressaltam que as barragens de água ou de rejeitos minerais são elementos contidos às regiões de acumulação capitalista ${ }^{1}$, planejadas pelo governo e apoiadas em sua produção por grandes e médias mineradoras (ou vice-versa). As barragens de mineração, apesar de buscarem mitigar problemas relacionados à geração de elevado volume de rejeito, contudo oferecem altos riscos de desastres ambientais.

Historicamente, as noções de riscos ambientais estão associadas à concepção de sociedade de risco (BECK, 2010; GIDDENS, 2000) ${ }^{2}$, elaboradas no contexto de reconfiguração da modernidade capitalista. Nas sociedades, os riscos vinculados à ideia de progresso, seguidos ou não de desastres ambientais, são constantes e se fazem sentir mais perigosos a partir do século XX. No setor mineral isto ocorre, particularmente, quando as estratégias políticas governamentais e empresariais visam de maneira mais frequente a preparação regional de espaços econômicos de extração mineral, destinados à crescente exportação in natura ou como produtos semi-acabados, exigindo uma exploração cada vez mais intensa. Fenômeno esse que se deu com maior ímpeto na segunda metade do século XX no Brasile nos demais países ou regiões periféricas ricas em matérias-primas. Consequentemente, os riscos ambientais ficaram mais sérios e as ocorrências de contaminações e outros impactos ambientais mais recorrentes.

No caso das barragens de mineração, elas surgem para solucionar o problema do destino dos rejeitos, que eram descartados sem normas ambientais pré-estabelecidas no ambiente, inclusive em cursos d'água. De maneira crescente, barragens de rejeito foram construídas e multiplicadas pelas empresas mineradoras ao longo do último século. Em consequência, vazamentos e rompimentos de reservatórios de resíduos se tornaram cada

\footnotetext{
Por região, conceito caro ao pensamento geográfico, entende-se as unidades espaciais delimitadas de acordo com um recorte temático do espaço. Diferentemente das regiões naturais, as regiões são dotadas de características físicas, políticas e econômicas específicas, que contam com a existência de conexões entre lugares, próximos ou distantes, por meio de redes. As regiões econômicas são planejadas e construídas por seus atores. Elas são, portanto, resultantes de decisões governamentais, com participação, principalmente, das empresas, públicas e privadas, e das corporações financeiras, nacionais e internacionais, com papel reduzido das sociedades locais. Em outros casos, elas podem surgir de decisões empresariais e serem estimuladas e suportadas pelos governos.

Por regiões de acumulação capitalista estamos entendendo regiões estratégicas físicas e socioeconômicas, que seguem o cenário de interações com a escala internacional. Considerando as crescentes demandas internacionais por recursos naturais, as regiões resultam de decisões e ações com o sentido de torná-las atraentes ao capital internacional e nacional interessados nos recursos territoriais. Regras e controles econômicos, investimentos infraestruturais e motivações econômicas são criadas visando maior lucratividade nos processos acumulativos capitalistas.

2 Originalmente, Beck, U. (1986) Risikogesellschaft: Aufdem Weg in eine andere Moderne.e Giddens, A. (1999) Runaway Word.
} 
vez mais recorrentes pelo mundo até a década de 1980. Posteriormente, apesar dos números de incidentes com barragens terem diminuído, elevaram-se os eventos graves e muitos graves (BOWKER; CHAMBERS, 2015; SANTOS; WANDERLEY, 2016).

As histórias dos empreendimentos mineradores no Brasil e no mundo revelam, entre outras coisas, as ainda frágeis regulações ambientais, sobretudo, em regiões e países mínero-metalúrgicos periféricos, sujeitos a riscos e, consequentemente, a desastres. Essas "regiões de riscos ambientais"3 são unidades espaciais construídas, que estão ainda em progresso de formação, tanto do ponto de vista da construção metodológica por técnicos que as criam, como na percepção dos grupos e indivíduos que vivem na região. Elas são recorrentemente produzidas ou reproduzidas e intencionalmente articuladas sob diferentes escalas geográficas ${ }^{4}$ no bojo do processo capitalista de produção desigual do espaço.

No caso brasileiro, com forte viés desenvolvimentista ${ }^{5}$, essas unidades espaciais de risco correspondem aos efeitos das regiões de acumulação capitalista, (re)produzidas com investimentos provenientes do Banco Nacional de Desenvolvimento Econômico e Social - BNDES, do Banco da Amazônia - BASA, do Banco Internacional para Reconstrução e Desenvolvimento - BIRD (Banco Mundial), do Banco Interamericano de Desenvolvimento - BID, de bancos europeus, de bancos estadunidenses, de bancos japoneses e, mais recentemente, de bancos chineses.

Tanto no caso do Sudeste, mais antigo, quanto do Norte do Brasil, mais recente, não podemos nos limitar a mencionar barragens de uma só empresa, nem de um só vale, compreendendo-as como um conjunto ou um complexo de barragens regionais. Tais barragens compõem as regiões mineradoras ou mínero-metalúrgicas sob risco ou impactadas por desastres ambientais. Regiões de acumulação que foram concebidas, planejadas e construídas no contexto de projetos de modernização industrial da economia brasileira desde o século XX, com objetivo de constituir maior articulação e participação com as demandas do mercado mundial.

\footnotetext{
Por regiões sujeitas aos riscos ambientais ou "regiões de riscos" estamos entendendo regiões de acumulação ou seus reversos (áreas não incorporadas à acumulação, mas que estão interligadas em redes com a região de acumulação, por exemplo por redes fluviais), nas quais os ambientes naturais quando alterados oferecem perigos e danos aos moradores locais e aos ecossistemas. Os riscos podem também ser agravados, em virtude de obras mal construídas, mal planejadas ou por opções de menor custo, mas com menos segurança. Ou ainda por mau uso e falhas de controle. Tais comportamentos podem significar haver menor cuidado com os ambientes e as populações locais atingidas, em favorecimento de uma maior acumulação do capital. Nessas regiões, os riscos são concentrados, o que requer considerar o conjunto de riscos ambientais dos diversos empreendimentos que nessas regiões estão abrigados.

4 Há interesse pela interação entre escalas. Muito mais do que atender às sociedades locais, nessas regiões as "novas" infraestruturas têm finalidade de reduzir os riscos econômicos dos investidores atraídos, visando a eficácia na inserção do local/regional e do nacional na "economia-mundo".

5 Por desenvolvimentismo entendemos desenvolvimento associado à industrialização, com pouco atenção às questões locais/ regionais. Neste contexto político-econômico, os capitais para impulsionar o processo são obtidos junto ao Estado, aos bancos estrangeiros e nacionais, às empresas estrangeiras e nacionais. (Vide descrição de P. Sandroni, 2007, p. 242).
} 
Nas regiões de mineração industrial, a densidade de barragens de rejeitos é relativamente alta, por isso são consideradas igualmente como produtoras de regiões de riscos, ainda que as mesmas não coincidam perfeitamente. Ademais, esses riscos são agravados com as variações nos preços das commodities minerais, que aumentam as possibilidades de cidades e campos no entorno das barragens serem duramente afetados por derramamentos de rejeitos estocados da mineração (DAVIES; MARTIN, 2009).

Preocupamo-nos com as escalas e níveis diferenciados de análise espacial e de ação política dos atores responsáveis e dos atingidos por desastres ambientais da mineração. A concentração na escala regional se justifica pela predominância das ações estatais e empresarias nesse nível escalar, por meio de projetos de desenvolvimento pautados na indústria de extração mineral destinados à área geográfica específica, com pouco ou nenhum diálogo com as sociedades e os projetos em escala local/regional. No entanto, os próprios desastres constroem novas escalas que interconectam atores anteriormente dispersos e desarticulados.

A criação de escalas regionais de acumulação por meio da mineração associa-se a processos de transformações espaciais, físicas e sociais, que estão vinculados diretamente à produção de espaços de riscos ou de desastres. Nesse artigo, propomos então abordar a problemática das (re)formações de regiões de acumulações capitalista, nas quais a questão do desenvolvimento econômico e a questão ambiental tornam-se centrais diante da interrelação entre o processo de acumulação e os acontecidos ou riscos de desastres ambiental.

Esse artigo visa, portanto, examinar o processo continuado de criação de escalas politicamente concebidas em forma de espaços regionais de acumulação capitalista e de risco ambiental. Nossa abordagem está fundamentada, particularmente, nos trabalhos de Henri Lefebvre (1991), David Harvey (1996) e Stephen Bunker \& Paul Ciccantel (2005). Defendemos que a questão geográfica central a ser abordada refere-se à necessária compreensão de que as regiões de acumulação mínero-metalúrgica são concebidas a partir da existência de riquezas naturais economicamente valorizadas no mercado internacional. Dessa forma, com o propósito de ampliar ganhos econômicos, os governos criam unidades geográficas estratégicas aptas a responderem aos interesses das mineradoras exportadoras de matérias-primas in natura ou semi-beneficiadas. Como era de se esperar, o complexo minerador em exploração produz regiões sujeitas aos riscos ambientais. Para a contribuição nesse debate nos apoiaremos, sobretudo, na noção de risco de "A Sociedade de Risco" de Ulrich Beck (2010) e nas noções de políticas de escalas e de políticas de espaço (COX, 1998; SMITH, 2004; SWYNGEDOW, 2004). 
Escolhemos para essa análise duas regiões (corredores) econômicas que não podem ser comparadas entre si facilmente, por participarem de processos socioambientais em tempos e espaços físicos-geográficos diferentes. Todavia, elas participam conjuntamente do processo de avanço do capital minerador no Brasil e de seus desastres associados. Deste modo, as regiões são tomadas nesse artigo como exemplos empíricos significativos da relação entre regiões de acumulação capitalistas e de riscos de desastres ambientais.

A primeira região selecionada situa-se na porção Sudeste do país. Trata-se da região mínero-metalúrgica, de criação mais antiga, a partir da década de 1940, que contempla partes dos estados de Minas Gerais, Espírito Santo, Rio de Janeiro e São Paulo. Parte dela, foi afetada pelo desastre ambiental conhecido popularmente como desastre da Samarco ou de Mariana, na bacia do Rio Doce. A outra região de acumulação selecionada encontrase no Norte do país, no estado do Pará, sendo de criação mais recente, a partir da década de 1970. Nessa região atuam a Mineração Rio do Norte-MRN e a Alunorte (hoje, Hydro Alunorte), que compõem parte da cadeia do alumínio na Amazônia brasileira. Nessa região, a Alunorte, desde a década de 1990, é responsável por repetidos vazamentos de barragens de rejeito no município de Barcarena/PA.

Discutir desastres ambientais no setor da mineração industrial sem relacioná-los com os processos de inserção dos Estados nacionais e regiões na economia mundial acaba sendo um debate descolado dos contextos norteadores das ambições e das ações políticas estatais, assim como empresariais. Esse é o caso da mídia que recorrentemente tem tratado o vazamento da Alunorte (em 2009) e o rompimento da barragem da Samarco (em 2015) como casos únicos (ou mesmo pontuais) no Brasil. Na lógica dessa abordagem midiática, a Samarco ou a Alunorte são empresas isoladas e não são tratadas como partícipes de projetos econômicos estatal-empresariais, que incluem a construção de escalas regionais planejadas, em áreas dotadas de recursos minerais ou energéticos.

É necessário deixar claro que esse trabalho não tem o intuito de comparar os desastres ambientais gerados em situações específicas, em função de condições físicas, ou seja, de geologia e topografia diversas, de rejeitos depositados em barragens construídas por diferentes condições de terreno e técnicas construtivas, além de serem marcados por povoamento distinto e por desastres de diferentes magnitudes. Em ambos os casos, a responsabilidade e a causalidade dos desastres são questões centrais. Em suma, a nossa intenção é, sobretudo, de tomá-los como exemplos de desastres que não são apenas ecológicos, mas também socioeconômicos e que, longe de serem casos únicos e isolados, ilustram desastres ambientais típicos de regiões mineradoras ou mínero-metalúrgicas estrategicamente reproduzidas no país. Nosso pressuposto é de que essas regiões vêm sendo recorrentemente criadas como 
opções de acumulação capitalista das empresas mineradoras, em “áreas novas”, ricas em recursos naturais, na qual as preocupações com os cálculos dos riscos econômicos são superiores às dos riscos ambientais.

\section{BARRAGENS, RISCOS E DESASTRES AMBIENTAIS}

Barragens de rejeitos da mineração implicam em riscos de desastre por rompimento ou vazamento, em um primeiro momento, e em ocorrências de desastres ambientais, posteriormente. A barragem da mineração é uma construção técnica, que pretende estocar rejeitos para resolver o problema de descarte do material inútil, sem valor para o mercado. Assim, as barragens, que se supõem rigorosamente avaliadas e reguladas pelos órgãos de controle de sua operação e construção, tornam possíveis os trabalhos de extração do minério ou de transformação mineral.

No âmbito dos recentes governos desenvolvimentistas no Brasil, intensificaramse a velocidade dos investimentos privados na mineração, por eles atraídos, e se reduz a chamada "intervenção estatal" nessas "novas" regiões e nesse setor da economia, em particular. As empresas mineradoras, por sua vez, visam: a) exploração segundo técnicas e tecnologias industriais para reduzir os custos e permitir ganho em escala (volumes cada vez mais elevados) ou, mais raramente, em qualidade do produto; b) estocagem de rejeito cada vez mais volumoso com técnicas e tecnologias menos onerosas.

Dessa forma, comumente, na literatura mais recente as barragens são consideradas como objetos técnicos, que podem gerar riscos seguidos de "desastres tecnológicos". Tais denominações podem ser explicadas pela referência ao caráter industrial da exploração mineral recente (vide ZHOURI et al., 2016). Segundo Carlos Vainer ${ }^{6}$, os eventos catastróficos da mineração deveriam ser denominados de "desastre público/privado", considerando as responsabilidades do Estado na regulação e fiscalização ambientais e trabalhistas, como também ao fornecer empréstimos, e das empresas mineradoras ou de transformação mineral, que, certamente, transgrediram regras e preservaram custos.

Os governos e as empresas buscam a exportação de minérios para países centrais e industriais em crescimento, que importam grandes quantidades de minério com o teor de concentração, em geral, de cerca de 60\%. Ou seja, principalmente os países desenvolvidos preferem pagar um pouco mais por uma matéria-prima semi-beneficiada livre de rejeitos, do que estocá-los em seus ambientes. Isto corresponderia aos países mineradores estocarem

\footnotetext{
Sugestão apresentada por Carlos Vainer feita a Andréa Zhouri em mesa redonda por ela coordenada no "Seminário Internacional Capitalismo Extrativo, Conflitos Territoriais e os Direitos das Populações Atingidas”, realizado entre os dias 27 e 30 de setembro de 2016.
} 
em barragens de rejeitos um valor quase sempre superior a 40\% de material inútil - ou seja, mais de dois quintos do total de material extraído.

Os vazamentos e rompimentos de barragens de rejeito são causados, na maioria das vezes, por falhas humanas de planejamento, de construção e de operação ou por ausência de monitoramentos eficazes. Ainda assim, os fatores eleitos como mais prováveis para apontar os indícios de ocorrências podem não ser bem apontados por especialistas contratados ou podem não ser devidamente controlados pelos reguladores e gestores públicos e privados. Os descontroles gerados por motivações temporais de crescimento do volume de produção das empresas, determinados por situações que quebram a rotina, são, na maioria das vezes, pouco avaliados. As normas, medidas, ações ambientais e adaptações exigidas pelos órgãos públicos e pelo corpo técnico, assim como os monitoramentos rotineiros, nem sempre são seguidos e respeitados por todos os envolvidos nas fases de produção.

Os riscos ambientais podem se materializar em desastres (ou hazards ${ }^{7}$, segundo alguns autores), que provocam perdas e danos às sociedades e ao ambiente. Para Brüseke (1997, p.121), que se fundamentou na visão de Beck, "risco é um acontecimento futuro, um momento esperado ou temido no qual essa perda pode acontecer". Segundo Hogan et al. (2004), risco (risk) é utilizado pelos geógrafos como uma situação futura que traz incerteza e insegurança. Ou seja, os riscos são probabilidades que informam sobre a possibilidade ainda incerta de ocorrência de perdas humanas, sociais, econômicas e ambientais, ainda que de diferentes magnitudes. Em suma, os eventos ambientais vistos como desastres, ou hazards, são associados à possibilidade de acontecimentos casuais futuros (Vide HOGAN, 2001, 2004; CUNHA; CARMO; OLIVEIRA, 2001).

As dinâmicas de cada desastre ambiental são diferentes e complexas e, além do mais, as variáveis a serem observadas são muitas. As incertezas quanto aos eventos ambientais danosos que ainda podem acontecer e quanto à eficácia dos procedimentos futuros de ação tendem a gerar conflitos. Tais conflitos expressam instabilidades e perdas reversíveis e irreversíveis. A passagem do risco ao desastre, naturais ou provocados por ações humanas, têm sido comuns na mineração e na transformação industrial. Os casos de desastres ambientais quando ocorrem em áreas ocupadas pelos seres humanos colocam em perigo a integridade das populações.

Desastre tem sido a palavra mais utilizada para expressar um acontecimento calamitoso, empresarial ou humanamente produzido. Todavia, as empresas tendem a considera-los inapropriadamente e denominam esse tipo de ocorrências como "acidente" (hazard). Desse

O termo também significa "acidente" (expressão que será utilizada apenas entre aspas nesse texto). 
ponto de vista, por ser uma ocorrência não prevista (súbita) e que pode ou não ocorrer causando danos e prejuízos a todos (tanto para a população quanto para a empresa, na primeira mais que sobre a segunda). As empresas não assumem as responsabilidades que lhes são competentes, nem tampouco os Estados. Sendo assim, sem o avanço da ciência e da tecnologia para geração de projetos de desenvolvimento industriais de menor instabilidade e danos às sociedades e às regiões, a quem cabe a responsabilidade ${ }^{8}$ pelo controle do futuro? A quem cabe minimizar os desastres ocorridos?

\section{OCORRÊNCIAS RECENTES DE VAZAMENTOS E ROMPIMENTOS DE BARRAGENS DE REJEITOS MINERAIS}

Em terrenos mais sujeitos a terremotos, como no oeste do Canadá e dos Estados Unidos da América, nos países ao longo da cordilheira dos Andes e no Japão, os casos de vazamento ou de rompimento de barragens são mais esperados e de difícil controle. Entretanto, onde os terrenos são mais estáveis, como no Brasil, rompimentos seriam em tese menos frequentes, mas outros fatores são causadores, como instabilidade do talude, erosão, chuvas fortes, vazamentos, excesso de deposição de rejeito e problemas na fundação e na estrutura das barragens.

O problema dos rejeitos da mineração no Brasil remonta aos anos de 1980 e 1990, com o conhecimento público de casos de desastres ambientais do setor mineral como: o assoreamento do lago Batata em Oriximiná (PA), no corredor da bauxita-alumina-alumínio no Norte do país; ou o rompimento da barragem do Grupo Itaminas, em Itabirito/MG, que causou a morte de sete pessoas (SANTOS; WANDERLEY, 2016).

Em 2006 e 2007, houve seguidamente dois desastres ambientais por rompimentos de barragens em Cataguases (MG), que contaminaram as bacias do Rio Pomba, causando danos em alguns municípios do sudeste do estado de Minas Gerais e do noroeste fluminense, deixando ao todo quatro mil desalojados em Muriaé (MG) e Miraí (MG) e contaminando o Rio Paraíba do Sul. Esses casos, entretanto, não serviram de aprendizado para que outros desastres fossem evitados futuramente.

Segundo o relatório do IBAMA, 508 "acidentes" ambientais foram registrados pelo órgão no ano de 2009. Nesse ano, destacou-se o caso de contaminação devido ao vazamento dos rejeitos industriais oriundos do processo de transformação da bauxita em alumina pela Alunorte, no município de Barcarena (PA), nas proximidades da região metropolitana de

\footnotetext{
8 Por responsabilidade entendemos o resultado do processo jurídico que envolve os que respondem pelas consequências das decisões, das ações e das operações que provocam alterações nas condições anteriormente vigentes, geradora de benefícios ou perigos que advêm do progresso tecnológico e econômico.
} 
Belém (PA). Esse evento causou o lançamento de rejeitos industriais de lama vermelha9 ${ }^{9}$ no Rio Murucupi, sem registro de mortes.

Em 2014, houve o rompimento de barragens de rejeitos da mineradora Herculano, na cidade de Itabirito (MG), causando a morte de três (3) indivíduos e deixando um ferido. Em cinco (5) de novembro de 2015, em Mariana (MG), na região central mineira, aconteceu o rompimento da barragem de rejeito de minérios de ferro da Samarco, atingindo o Rio Gualaxo do Norte, Rio Carmo e Rio Doce, esse último de maior extensão (853 km). A avalanche de lama gerada devastou o povoado rural de Bento Rodrigues, matando dezenove (19) pessoas, dentre moradores e trabalhadores da mineradora. A lama também atingiu o vale do Rio Doce e, consequentemente, pelo menos 30 municipalidades situadas ao longo do eixo principal do Rio Doce, em Minas Gerais e no Espirito Santo. Por fim, os rejeitos poluíram o Rio Doce e parte do litoral do estado do Espírito Santo, onde o rio desagua.

\section{POLÍTICAS DE ESCALA: REGIÕES MÍNERO-METALÚRGICAS DE RISCOS AMBIENTAIS E SEUS DESASTRES}

Insistimos que os projetos de região de acumulação capitalista ou de inserção mais contundente do local-nacional na economia mundial surgiram como estratégias geopolíticas e geoeconômicas (EGLER; PIRES DO RIO, 2003) de crescimento econômico elaboradas particularmente a partir da segunda metade do século XX. Na história das sociedades, as regiões econômicas são concebidas por agentes governamentais, formuladores e executores dos projetos políticos-territoriais, e por empresas privadas para elas atraídas. Esses últimos - projetos privados articulados às políticas públicas - se beneficiam, em geral, de isenções fiscais, estímulos creditícios e infraestruturais criados. Dessa forma, regiões econômicas são interligadas a outras escalas que abrigam redes produtivas de interesse do país e das empresas. Tais estratégias são, assim, concebidas, planejadas e reproduzidas em determinadas extensões espaço-temporais.

As empresas (dentre as quais as mineradoras), atores ou agentes sociais que também tornam as regiões realidades, se beneficiam de políticas de produção de unidades espaciais a partir de implantação de empreendimentos destinados à exploração de recursos com vistas ao atendimento das demandas dos mercados externos ou internos. Para isso, transformações espaciais e infraestruturais (por exemplo, a criação pontes, de estradas, ferrovias, hidrovias, portos, minerodutos ou, usinas hidrelétricas, cidades, etc.) são essenciais. Enfim, as empresas aos escolherem suas localizações se preocupam com que estrutura a região contará ou quais os custos extras para o aparelhamento regional.

\footnotetext{
9 O rejeito conhecido popularmente como "lama vermelha" é oriundo do processo de separação do alumínio de outros componentes. Para a realização desse processo, é utilizada principalmente soda cáustica, substância altamente alcalina, que faz com que a lama seja corrosiva e tóxica.
} 
A partir dos anos de 1940, no caso de Minas Gerais, no Sudeste do país, os projetos de regiões econômicas proliferam-se com base na mineração industrial e estímulos ao desenvolvimento da siderurgia no país. As minas foram conectadas aos portos e, paulatinamente, às indústrias de pelotização, do ferro-gusa e do aço, em Minas Gerais, no Espirito Santo, no Rio de Janeiro e São Paulo. No caso do Norte do país, houve um projeto composto por duas regiões. Uma região teve como base a exploração da bauxita e a produção e a geração de alumina e do alumínio primário no Norte, intensiva em energia. A outra baseou-se na extração do minério de ferro e na produção do ferro-gusa em Carajás (PA), processo intensivo no consumo de carvão vegetal. Esse subprojeto foi similar ao projeto de exploração do ferro que deu origem ao corredor mínero-metalúrgico da Estrada de Ferro Vitória-Minas no Sudeste do Brasil.

\section{Problemas Ambientais e Conflitos Socioambientais Gerados}

Qual é a relação entre risco, desastre e conflito em áreas de mineração? O conflito ocorre, geralmente, quando há mobilizações sociais por impasses motivados por desacordos quanto aos riscos ou às soluções (ou ausência de soluções) arranjadas pelas partes envolvidas, em situações de desastre e outros impactos. Os conflitos, de modo geral, abarcam atores sociais na maioria das vezes desiguais, organizados em movimentos de resistência ou reivindicações por um lado e empresas e/ou governos por outro. Por esse motivo, requerem negociações e mediação de agentes do Estado ou de outros terceiros.

Muitos dos conflitos ambientais com a população do entorno da mineração ou da metalúrgica são provenientes de riscos, isto é, de ameaças ambientais, ou também de desastres e impactos ocorridos. Os conflitos entre empresas mineradoras e órgãos governamentais, em particular da área ambiental como Instituto Brasileiro do Meio Ambiente e Recursos Renováveis - IBAMA e Instituto Chico Mendes de Conservação da Biodiversidade ICMbio, também são comuns. Contemporaneamente, os conflitos mais recorrentes são aqueles envolvendo as populações atingidas pelas ameaças ou pelos desastres e impactos já ocorridos. Em outras palavras, os crimes ambientais, as tensões e os conflitos deflagrados entre Estado e empresas mineradoras ou entre Estados e sociedade atingida são frequentes. Em muitos casos, o Estado e as empresas envolvidas criam histórias ou narrativas para ocultar ou minimizar os danos ocorridos e, consequentemente, diminuir as punições e compensações devidas.

Os desastres ambientais são um constructo da sociedade e encontram-se inerentes ao modo de produção capitalista (BECK, 1986). As mortes imediatas causadas são danos inestimáveis, mas não são as únicas tragédias sofridas pelos grupos sociais locais e pelos 
ecossistemas. Pode-se falar em seta do tempo na história regional antes e depois dos desastres ambientais vividos. As atividades econômicas, ou no caso da mineração as minas, são de explorações transitórias. Esgotadas as minas, as estruturas criadas para atender a produção, como as barragens de rejeito, continuarão existindo, oferecendo perigos constantes aos habitantes ao seu redor, mas não mais com monitoramentos cotidianos.

Além dos danos diretamente associados ao rompimento de barragens de rejeito de mineração, os habitantes locais/regionais enfrentam também problemas de águas contaminadas, rios e lagos assoreados. A metalurgia e o desflorestamento, motivado pela produção do carvão vegetal utilizado na produção do ferro-gusa, contribuíram para o desmatamento acelerado, que afetam diretamente os microclimas, os mananciais de água e os modos de vida locais no Sudeste e no Norte. Sem considerar a devastação desenfreada estimulada por outras atividades, como a atividade agropecuarista. Outro problema ambiental visto atualmente são os minerodutos, alternativa de transporte de minério que utilizam volumes consideráveis de água, causando a escassez ainda maior do recurso hídrico no local de extração.

Quando os desastres passam do risco potencial para o evento real, os impactos sociais ficam explícitos. Por impactos, entende-se mortes (imediatas e em longo prazo), mudanças (temporárias ou duradoras) nas condições de vida e dos ecossistemas e outras alterações na vida individual e coletiva. Os impactos são processos que não acabam com o fim do desastre (entendendo-o como o detonador). As qualidades de vida da população humana e animal ou dos ambientes físicos e sociais tendem a refletir esse processo continuado que advém também das medidas tomadas para mitigá-los ou compensá-los.

\section{Projetos de Regiões de Mineração e de Transformação da Bauxita e do Ferro}

Considerando as situações dos dois exemplos por nós aqui analisados - a região econômica em formação do complexo do alumínio na Amazônia e a região econômica Ferrífera de Minas Gerais -, ressaltamos que ambas são regiões econômicas de limites flexíveis, fundamentadas nas minas em exploração, nas indústrias de transformação mineral e nos portos, elementos responsáveis pelas configurações regionais. Ambas são concentradoras de riscos ambientais e que demostraram ineficácias públicas e privadas na regulação e gestão ambiental.

O complexo da Bauxita-Alumina-Alumínio na Amazônia Oriental, uma Região Econômica no Pará ${ }^{10}$ em Formação

10 Consideramos para efeito dessa análise, ser essa uma sub-região de uma região econômica mais ampla que abrange a Amazônia oriental incluindo sudeste e leste da Amazônia e médio/baixo vale do Rio Amazonas, norte da Amazônia oriental. Isto é, uma 
Essa região de acumulação que foi planejada na década de 1970, tratava-se da criação de um segundo corredor mineiro, dessa vez de bauxita-alumina-alumínio, concebido muito após o corredor Serra do Navio de manganês, estabelecido na década de 1950. Em um contexto de modernização industrial da economia brasileira à época, o corredor do complexo do alumínio foi inspirado e estimulado por interesses empresariais e estatais japoneses, que pretendiam se tornar compradores diretos.

Figura 1: Regiões Mínero-Metalúrgica e Portos no Norte Brasileiro (Corredores de Exportação de Minérios) - 2010

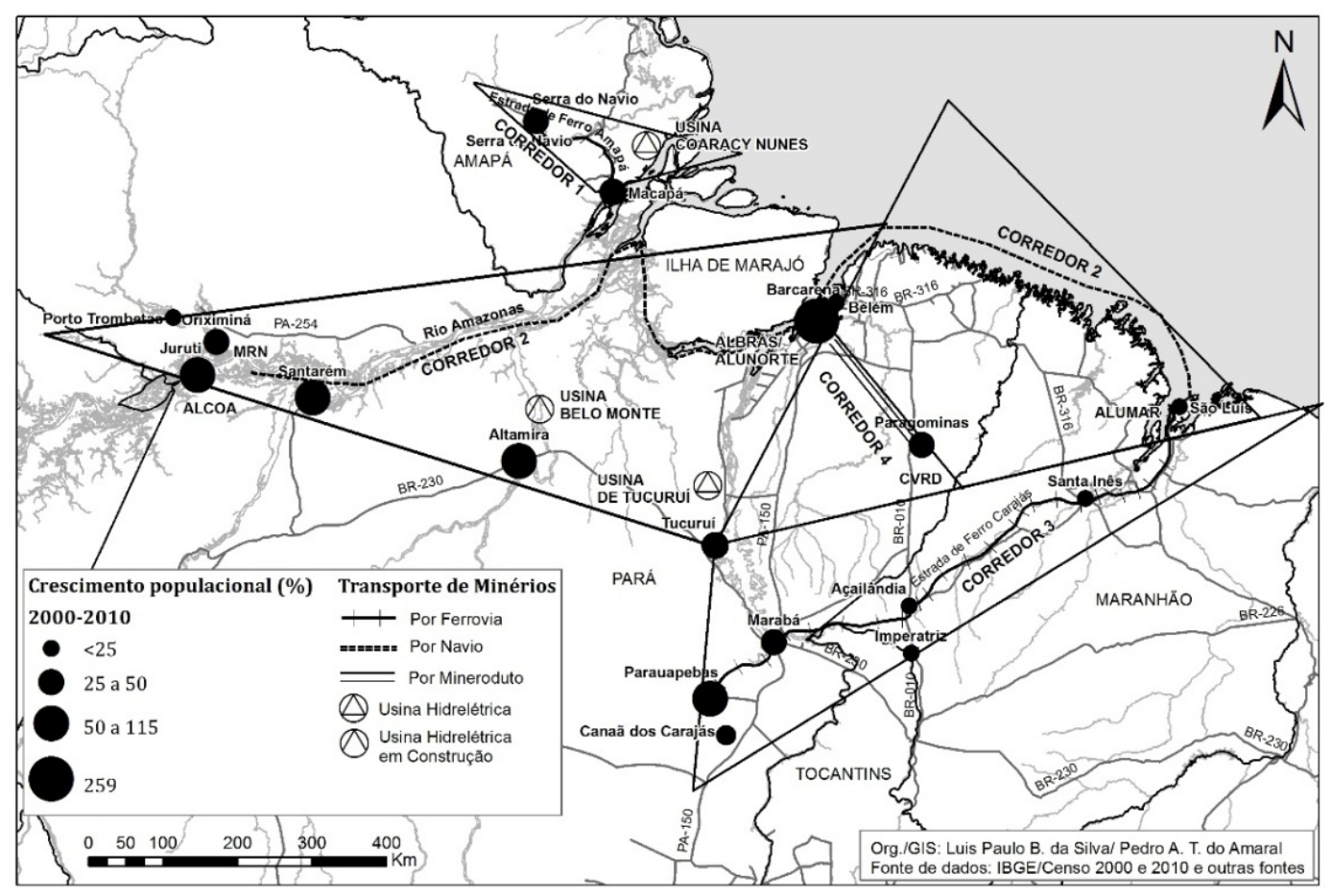

Fonte: COELHO, MONTEIRO, BARBOSA, 2012.

Os corredores de exportação foram formados pelas hidrovias do Rio Trombetas e do Rio Amazonas. Por meio desses rios as matérias-primas são transportadas até o porto de Vila do Conde, em Barcarena no Pará, onde se instalaram a Albrás (Alumínio Brasileiro S.A.) e a Alunorte (Alumina do Norte S.A), ou até o porto da Alumar da Alcoa, em São Luís do Maranhão. Essa região de acumulação do alumínio pode ser representada por um triangulo formado por três vértices: as minas de bauxita, a Usina Hidrelétrica de Tucuruí e os portos em Barcarena no Pará ou de São Luís do Maranhão. Outros corredores foram

região composta de sub-regiões (corredores). Entre seus corredores destacam-se o corredor do manganês na Serra do Navio, o corredor da bauxita-alumina-alumínio, o corredor de Carajás no sudeste do Pará, os corredores de Paragonimas e do caulim no leste paraense. 
a ele acrescentados pela expansão da atividade de mineração do caulim e da bauxita no leste do estado do Pará, resultando um somatório de triângulos (Figura 1).

O projeto da Mineração Rio do Norte - MRN foi lançado em condição de crise mundial energética (a crise do petróleo de 1973) e durante o período de autoritarismo do Estado brasileiro, uma vez que o país se encontrava em pleno regime ditatorial (1964-1985). No contexto de geopolítica da energia, a Albrás tinha como objetivo fornecer alumínio para o mercado japonês, uma vez que o Japão não dispunha de energia abundante nem de matérias - primas. Já a Alunorte foi planejada para produzir alumina a partir da bauxita, para posterior transformação em alumínio. A Alunorte foi constituída em julho de 1978, no mesmo ano da Albrás. Frisa-se, no entanto, que a Alunorte entrou em funcionamento só em 1995.

As três empresas surgiram tendo a Companhia Vale do Rio Doce (atual Vale S.A.) como acionista principal. Enquanto os japoneses eram acionistas das indústrias de transformação, outras empresas multinacionais e nacionais do ramo da mineração completavam a composição acionária da MRN. Ressalta-se que o processo de transformação de alumina em alumínio primário é intensivo em energia, que na Amazônia é provinda da Usina de Tucuruí, e também, assim como a extração, grande gerador de rejeitos. Os japoneses eram os principais estimuladores da usina de Tucuruí, mas não participaram de seu financiamento, deixando o custo para o Estado brasileiro (BUNKER, 1985; BUNKER; CICCANTELL, 2005).

Tanto a Albrás quanto a Alunorte foram construídas em Barcarena (PA), situada a 40 quilômetros de Belém (PA). O distrito industrial de Barcarena representa um esforço de integração da cadeia produtiva do alumínio no Pará e de verticalização da economia, atendendo o projeto nacional desenvolvimentista. Contudo, pouco se alcançou ao longo de mais de trinta anos do início da instalação do complexo do alumínio na Amazônia oriental.

As atividades associadas à extração da bauxita e à produção de alumina e de alumínio deram origem ao que vamos denominar "região de acumulação do alumínio", planejada na segunda metade da década de 1970 e ainda em fase de consolidação (Figura 1). Esse complexo foi formado pela Mineração Rio do Norte, responsável pela exploração da bauxita, que em grande parte segue para a Alunorte (hoje Hydro Alunorte), em Barcarena (PA), e, após transformação em alumina, abastece a Albrás, onde é transformada em alumínio primário, com energia da hidroelétrica de Tucuruí. Outra parte do minério segue diretamente para exportação sem agregação de valor. Mais tarde, esse recorte de região foi complementado por outras vertentes: a extração de bauxita de Juruti pela Alcoa, diretamente exportada ou transportada para a transformação na Alumar em São Luís (MA); e as minas de bauxita 
antes do Grupo Vale S. A. em Paragominas (PA), transportadas por mineroduto até a Alunorte (Hydro Alunorte), em Barcarena (PA).

Os projetos Juruti e Paragominas foram lançados mais de 30 anos depois do surgimento da MRN, já nos anos 2000, em pleno período de abertura política, em outro contexto da política territorial estatal, também desenvolvimentista e de intensa globalização de capitais. Esses projetos vieram redesenhar o complexo mínero-metalúrgico do alumínio, pelo menos do ponto de vista da diversificação da oferta de matéria-prima primária por novas empresas e minas, a Alcoa em Juruti (PA) e a Vale S.A em Paragominas (PA).

Em 2010, a parte da Vale S.A. das ações da Alunorte e da Albrás, assim como o projeto Paragominas, foram vendidos para a empresa norueguesa Norsk Hydro. Assim, nesse ano, a composição societária da Alunorte foi alterada, aumentando a participação da norueguesa Norsk Hydro de $25,25 \%$ para 34,03\% e reduzindo a dos japoneses da NAAC - Nippon Amazon Aluminium Co de 8,24\% para 5,32\% no capital total da companhia. Na Albrás, a norueguesa possui $51 \%$ das ações e a NAAC $49 \%$.

As regiões econômicas não são recortes espaciais isolados de outros processos econômicos, sendo sobrepostos por outras formas de acumulação. No caso da região de acumulação do alumínio na Amazônia Oriental, outros corredores de exportação de matérias-primas como manganês, caulim e grãos (soja e milho) convergem para Barcarena (PA) e compõem o espaço regional.

\section{A Região Ferrífera de Minas Gerais e a metalurgia em MG-ES-RJ-SP}

A história do ferro em Minas Gerais foi precedida pela história do ouro e do diamante no período colonial. A área central desta região incluía antigas minas de ouro e diamante e minas de ferro relativamente novas, do final do século XIX e do século XX, localizadas principalmente no Quadrilátero Ferrífero ${ }^{11}$. A formação da região econômica voltada para a exploração e transformação do minério de ferro (mas também de outros minérios, como o ouro e o alumínio), ou "região mínero-metalúrgica do Ferro" no eixo Minas Gerais, Espírito Santos, Rio de Janeiro e São Paulo, intensificou-se na segunda metade do século $\mathrm{XX}$, sendo atualmente um fato consumado.

A história do setor da mineração de ferro em Minas Gerais, mais particularmente, remonta a 1921, com a criação da Companhia Siderúrgica Belgo-Mineira, atual ArcelorMittal, contando com a participação tanto do consórcio belgo-luxemburguês Arbed quanto de

\footnotetext{
${ }^{11}$ Quadrilátero Ferrífero é uma área que encerra a província geológica que contém terrenos pré-cambrianos ricos em ferro e outros minerais, localizada no centro-sul do estado de Minas Gerais. Nesse Quadrilátero, encontram-se duas bacias hidrográficas importantes: do Rio das Velhas e do Rio Doce. A área do Quadrilátero é de aproximadamente 7 mil quilômetros quadrados.
} 
empresários locais. A usina em João Monlevade (MG) foi inaugurada em 1939, sendo, à época, a maior siderúrgica integrada a carvão vegetal do mundo.

Em 1940, houve a construção da Companhia Siderúrgica Nacional (CSN) pelo presidente Getúlio Vargas, durante o Estado Novo (1937 - 1945), em Volta Redonda (RJ). A CSN, que recebia ferro extraído em Minas Gerais, começou a produzir ferro-gusa e lingotes de aço, porém, começando a operar efetivamente no ano de 1946, durante o governo do presidente Eurico Gaspar Dutra. A Companhia Ferro e Aço de Vitória (Cofavi), por sua vez, foi fundada em Vitória, em 1942.

Com início da produção em 1951, a Aços Especiais Itabira (Acesita) em Itabira (MG), antes controlada pelo Banco do Brasil, direcionou-se à produção de aços especiais, assim como o complexo da mina de Pau Branco (na área de Brumadinho-MG) e da siderúrgica da Companhia Siderúrgica Mannesmann em Belo Horizonte (MG), criada em 1952 como subsidiária da empresa alemã de mesmo nome. A Mannesmann ${ }^{12}$, responsável pela operação do primeiro forno elétrico de redução de minério de ferro, dedicava-se a produzir tubos com e sem costura.

Em 1952, foi criado o Banco Nacional de Desenvolvimento Econômico (BNDE), atual BNDES. Desde sua criação, o BNDE participou do processo de criação de empresas mínerometalúrgicas. Ainda na década de 1950, alguns projetos do setor contaram com apoios governamentais, como a ampliação da Belgo-Mineira, em 1953. O BNDE entrou também no capital das Usinas Siderúrgicas de Minas Gerais S. A. (Usiminas ${ }^{13}$ ), fundadas em 1956, para complementar a participação do governo estadual, cujos recursos eram insuficientes.

A Samarco surgiu na década de 1970 com a participação acionária da S A Mineração da Trindade (Samitri) e da Marcona Corporation. A empresa foi criada como parte relativamente recente dessa história, em 1973. Hoje ela é uma joint venture cujas ações pertencem a duas empresas multinacionais: a Vale S.A., com sede no Brasil, e a anglo-australiana, BHP Billiton ${ }^{14}$.

A partir da área central de Minas Gerais e do Quadrilátero Ferrífero Mineiro, organizou-

12 A Mannesmann concentrava em Minas Gerais uma unidade de mineração (Mina Pau Branco no município de Brumadinho, a $40 \mathrm{~km}$, de onde segue a matéria-prima) e uma siderúrgica (Usina Barreiro, Belo Horizonte), adquiridas pela francesa Vallourec, passou a ser Vallourec \& Mannesmann Tubes, com a sua aquisição total hoje é Vallourec Tubos do Brasil. A Vallourec, hoje, possui uma nova usina siderúrgica, no município de Jeceaba-MG, em parceria com a japonesa Sumitomo Metals, inaugurada em 2007. A ferrovia construída liga as estruturas da Vallourec os estados de São Paulo, Rio de Janeiro e Espírito Santo.

13 Usiminas (Usinas Siderúrgicas de Minas Gerais S.A) é uma empresa do setor siderúrgico voltada para a produção e comercialização de aços planos laminados a frio e a quente, bobinas, placas e revestidos, destinados principalmente aos setores de bens de capital e de bens de consumo da linha branca, além da indústria automotiva. Foi fundada em 1956 e inaugurada em 1962 em Coronel Fabriciano, no então distrito de Ipatinga (MG). Dois anos depois, a Usiminas tornou-se uma joint venture, numa composição entre capital estatal e acionistas japoneses.

${ }^{14}$ Em Mariana (MG), a Samarco mantém a atividade de extração mineral e a produção de pelotas de ferro assim como sua exportação, ocorre em Anchieta (ES). 
se um recorte regional fundamentado em empresas da CVRD/Vale. S. A., da Companhia Siderúrgica Belgo-Mineira/ArcelorMittal, da CSN e da Usiminas. Hoje o arranjo espacial da região de acumulação mínero-metalúrgica do Sudeste é mais complexo, composto por diversas mineradoras como destaque para Vale S/A; CSN, Mineração Usiminas S.A (MUSA), Ferrous Resources do Brasil e Samarco S/A. No setor da siderurgia, a diversificação é ainda maior, com 26 usinas nos quatro estados do Sudeste, de um total de 35 no Brasil. Dentre as principais empresas siderúrgicas estão a CSN, Usiminas, Gerdau, Votorantim, ArcelorMittal, Companhia Siderúrgica do Atlântico (CSA) ThyssenKrupp, dentre outras, que compõem os 11 grupos empresariais brasileiros.

A região da mineração e de transformação do ferro, ainda em formação, incluí relações que se fazem ao longo de dois eixos: um corredor composto pelo vale do Rio Doce e pela Estrada de Ferro Vitória-Minas; e os outros corredores formados pela Estrada de Ferro das Minerações Brasileiras Reunidas (MBR), antes do grupo Caemi que detinha a MRS Logística ${ }^{15}$ (concessionária que opera a chamada Malha Regional Sudeste da Rede Ferroviária Federal S. A.). Os corredores eram voltados para o escoamento de minérios do interior de Minas Gerais e para trazer o carvão mineral para siderurgia, vindo de fora da região. O minério de ferro seguia, e ainda segue, em uma direção para o porto de Vitória e noutras direções tomavam os rumos dos portos do Rio de Janeiro e de São Paulo.

A região mínero-metalúrgica do Sudeste ainda mantém grande parte das rotas originárias, conectando as minas de ferro do Quadrilátero Ferrífero, em Minas Gerais, às cidades de indústrias siderúrgicas como Ipatinga (MG), Volta Redonda (RJ), Rio de Janeiro (RJ), Vitória (ES) e às áreas portuárias do Espírito Santo, Rio de Janeiro e São Paulo. Entretanto, os minerodutos construídos primeiramente pela Samarco S/A, em 1977, para ligar a mina de Mariana (MG) à pelotizadora no porto de Ubu, em Anchieta (ES), e em maior número a partir dos anos 2000 pela própria Samarco e pela Anglo American, ligando a mina em Conceição do Mato Dentro (MG) ao Porto do Açu (RJ), ampliaram os eixos de circulação do minério de ferro em direção ao litoral do Norte do Rio de Janeiro e Sul do Espírito Santo.

A região econômica pesquisada que expandiu sua envergadura além do Quadrilátero Ferrífero mineiro e que possui Belo Horizonte como centro econômico-financeiro e políticoadministrativo, pode ser representada, grosseiramente, em uma figura polifórmica (Figura

\footnotetext{
${ }_{15}$ A malha ferroviária sob gestão da MRS estabelece conexão entre centros de produção e de consumo. Vincula as áreas produtoras aos cinco portos do Sudeste do país: Rio de Janeiro (RJ), Itaguaí (RJ), Sepetiba (RJ), Santos (SP) e o terminal privativo de embarque de minério de ferro de propriedade da MBR na Ilha de Guaíba, na Baía de Angra dos Reis (RJ). Atualmente, o controle da empresa é dividido da seguinte forma: Gerdau 2,37\% Usiminas Participação e Logística 19,92\%; Vale 19,26\%, CSN 27,83\% e Minerações Brasileiras Reunidas S/A - MBR 20,00\%, enquanto outros acionistas detém os 10,62\% restantes.
} 
2). Em Minas Gerais, ela abrange do município de Conselheiro Lafaiete até os municípios de Nova Lima, Belo Horizonte, Sete Lagoas e parte do vale do Rio das Velhas, abarcando, assim, a área central de Minas Gerais. Daí, vai ao oceano Atlântico por meio de ferrovia (E. de F. VitóriaMinas) pelo vale do Rio Doce. Em Vitória (ES) atinge os portos do sul do Espírito Santo e no Rio de Janeiro segue para Volta Redonda (RJ) e, posteriormente, para os portos na região metropolitana do Rio de Janeiro (RJ) e em Santos (SP), por meio de ferrovias. Para Rio de Janeiro e São Paulo, há também o trajeto via MBR, mencionada anteriormente. Acrescenta-se ainda outras rotas por meio dos minerodutos que acompanham o declive do relevo, descendo as encostas da Serra do Espinhaço em Minas Gerais. Conforme planejado, minério seguirá, assim, de Minas Gerais para o porto do Açu, no estado do Rio de Janeiro, ou para o Porto de Ubu, no Espírito Santo.

Figura 2 - Região Mínero-Metalúrgica e Portos no Sudeste Brasileiro

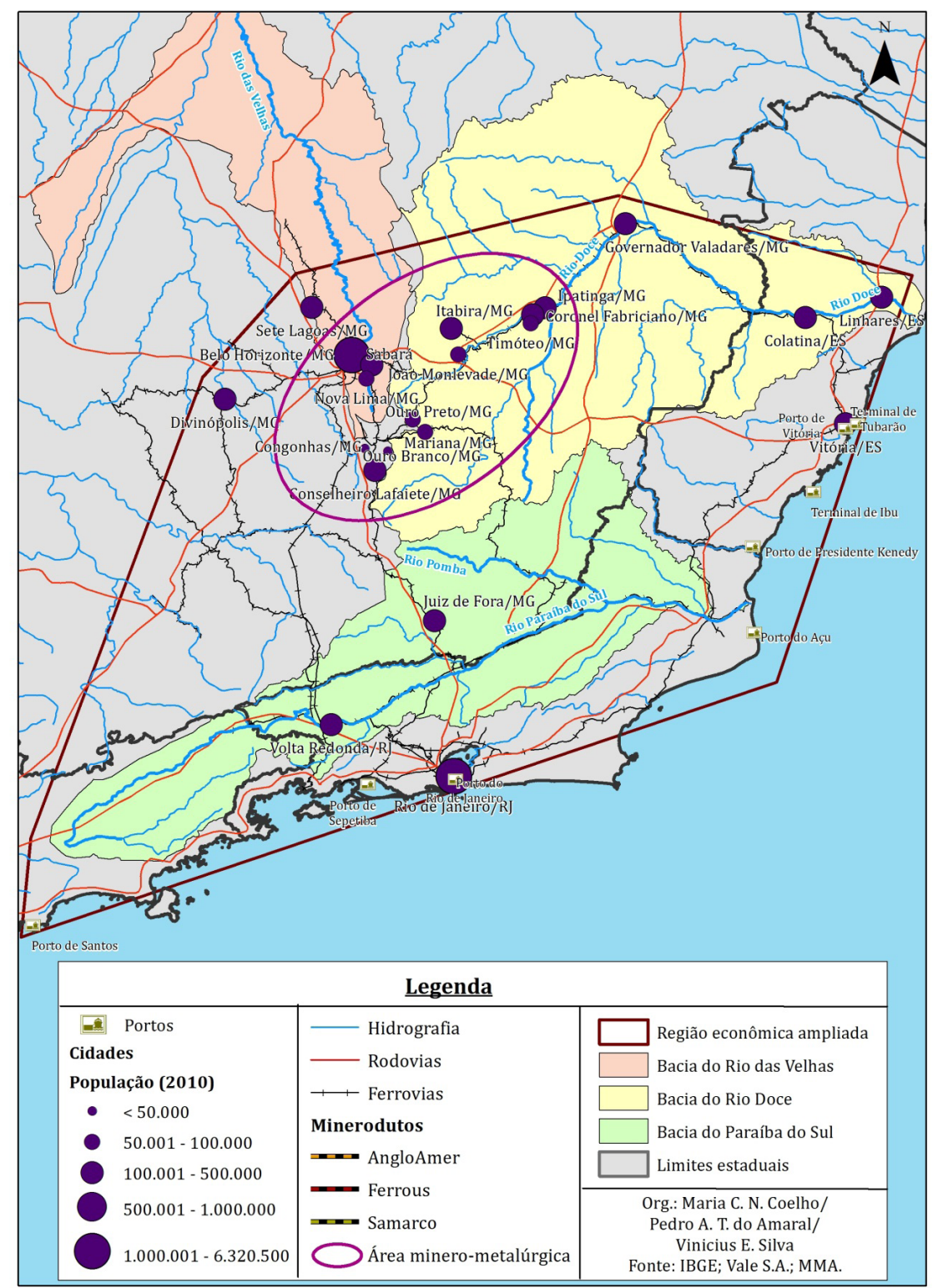


A região mínero-metalúrgica do Ferro consiste em uma região já historicamente voltada para a mineração e transformação do ferro, principalmente para a produção de ferro-gusa e aço, destinada tanto para o mercado interno quanto para a exportação. Tal região inclui municípios e portos (Quadro 1) conectados pelo corredor de exportação da Estrada de Ferro Vitória-Minas que acompanha a trajetória do vale do Rio Doce e outros corredores ferríferos que ligam minas e portos marítimos no Espírito Santo, Rio de Janeiro e São Paulo. Esses corredores de exportação atravessam lugares (municípios), ainda pouco articulados entre si e de industrializações às vezes precárias. Não obstante, no Sudeste os lugares (municípios) no trajeto dos corredores de exportação são mais integrados entre si do que ocorre nos corredores de exportação do Norte do país.

Quadro 1: Municípios e Capitais na Região Mínero-Metalúrgicos, do Sudeste do País

\begin{tabular}{|c|c|c|c|}
\hline $\begin{array}{l}\text { Municípios } \\
\text { principalmente } \\
\text { Mineradores }\end{array}$ & $\begin{array}{l}\text { Municípios } \\
\text { Metalúrgicos }\end{array}$ & $\begin{array}{l}\text { Portos Exportadores } \\
\text { de Aço e de } \\
\text { Minérios com áreas } \\
\text { industriais nas } \\
\text { adjacências }\end{array}$ & $\begin{array}{l}\text { Metrópoles } \\
\text { Nacionais, } \\
\text { Sedes de Empresas } \\
\text { Mineradoras e } \\
\text { Exportadoras } \\
\text { Capitais Estaduais } \\
\text { e Cidades } \\
\text { Regionais }\end{array}$ \\
\hline $\begin{array}{l}\text { Minas Gerais } \\
\text { - Congonhas-MG } \\
\text { - Conselheiro } \\
\text { Lafaiete-MG } \\
\text { - Itabira-MG } \\
\text { - Jeceaba-MG } \\
\text { - Mariana-MG } \\
\text { - Nova Lima-MG } \\
\text { - Ouro Branco-MG } \\
\text { - Ouro Preto-MG } \\
\text { - Sabará-MG }\end{array}$ & $\begin{array}{l}\text { Espírito Santo } \\
\text { - Anchieta-ES } \\
\text { - Cariacica-ES } \\
\text { - Vitória-ES } \\
\text { Minas Gerais } \\
\text { - Barão dos Cocais-MG } \\
\text { - Divinópolis-MG } \\
\text { - Ipatinga-MG } \\
\text { - Jaceaba-MG } \\
\text { - João Monlevade-MG } \\
\text { - Juiz de Fora-MG } \\
\text { - Ouro Branco-MG } \\
\text { - Sete Lagoas-MG } \\
\text { - Timóteo-MG } \\
\text { Rio de Janeiro } \\
\text { - Barra Mansa-RJ } \\
\text { - Resende-RJ } \\
\text { - Rio de Janeiro-RJ } \\
\text { - Volta Redonda-RJ }\end{array}$ & $\begin{array}{l}\text { Espírito Santo } \\
\text { - Porto de Tubarão-ES } \\
\text { - Ponta de Ubu-ES } \\
\text { Rio de Janeiro } \\
\text { - Porto do Açu-RJ } \\
\text { - Porto de Itaguaí-RJ } \\
\text { - Porto do Rio de } \\
\text { Janeiro-RJ } \\
\text { - Porto de Sepetiba-RJ } \\
\text { São Paulo } \\
\text { - Porto de Santos-SP }\end{array}$ & $\begin{array}{l}\text { Capitais dos estados } \\
\text { - Belo Horizonte-MG } \\
\text { - Rio de Janeiro-RJ } \\
\text { - São Paulo-SP } \\
\text { - Vitória-ES } \\
\text { Cidades Regionais } \\
\text { - Governador } \\
\text { Valadares-MG } \\
\text { - Juiz de Fora-MG }\end{array}$ \\
\hline
\end{tabular}

Fonte: Diversa. 
A região econômica correspondente ao complexo da bauxita-alumina-alumínio possui o porto do município de Barcarena. Para Barcarena convergem matérias-primas como bauxita, caulim e cereais (soja e milho, principalmente) que seguem em navios pelos rios Amazonas e Pará, de um lado, e os rios Tocantins e Capim (substituído por minerodutos), do outro. Os navios que saem de Barcarena fazem as conexões da navegação fluvial com a navegação marítima. Os terminais se multiplicaram recentemente para dar vazão à exportação de cereais. A zona portuária de Barcarena foi dotada de área industrial que ainda é, no entanto, pouco expandida e muito pouco diversificada, sem completar a cadeia produtiva, como era esperado, por exemplo, na cadeia do alumínio.

Na região econômica mínero-metalúrgica do Sudeste, além dos municípios mineiros ou de siderúrgicas próximas às minas ricas em matérias-primas, municípios portuários são encontrados. A capital mineira é o centro regional, por excelência, com parque industrial relativamente diversificado. Belo Horizonte é, sem dúvida, a mola propulsora da região mínero-metalúrgica. O município de Juiz de Fora, ligado por ferrovias e estradas de rodagens aos portos no Rio de Janeiro, tem adotado, com relativo sucesso, políticas voltadas a atrair indústrias siderúrgicas, bem como outras indústrias e serviços, fortalecendo-se assim como centro industrial e de serviços. Governador Valadares, uma cidade regional, no médio vale do Rio Doce, diferentemente, cresceu como importante centro administrativo, de comércio e serviço, mas funciona, fundamentalmente, como centro concentrador de atividades agropecuaristas. Os altos e médios vales do Rio Doce nas proximidades de Governador Valadares, além de terem permanecido sobretudo pastoris e de serem orientados a evoluir para à monocultura do eucalipto com a finalidade de produzir madeira para celulose para abastecer a Cenibra, são estimulados a produzirem energia elétrica por meio de hidrelétricas, interligadas ao sistema regional.

Na região econômica mínero-metalúrgica do Sudeste, as redes logísticas regionais são mais desenvolvidas. Elas conectam minas aos portos, ou minas aos municípios sede das minas ou das indústrias de transformação e estas aos portos. Além disso, outras indústrias, como a automobilística ao longo do eixo RJ-SP-MG, estimularam o transporte de materiais e produtos acabados, tanto por ferrovias ou estradas de rodagens, para os portos do Rio de Janeiro e São Paulo. Enfim, a região da mineração e de transformação metalúrgica de MG-ES-RJ-SP está em elaboração desde o início do século XX (Figura 2; Quadro 1) e se encontra bem mais consolidada do que a região econômica do complexo da bauxitaalumina-alumínio, no Norte do país (Figura 1). 


\section{DESASTRES AMBIENTAIS RECORRENTES NAS “REGIÕES DE RISC0": OS EXEMPLOS DA MRN E DA ALUNORTE NO ESTADO DO PARÁ E DA SAMARCO NO ESTADO DE MINAS GERAIS}

As barragens de rejeitos difundem-se em Minas Gerais e no Pará junto com novos projetos e expansões de antigos complexos de mineração. Os assoreamentos de lagos ou rios e as lamas derramadas pelo rompimento nos reservatórios eliminam vidas, animais e vegetais, empobrecendo os ecossistemas. Os exemplos selecionados de desastres ambientais da mineração ou das atividades de transformação mineral no Brasil, considerados pelas empresas envolvidas como "acidentes", ocorreram em Oriximiná (PA), na década de 1980, depois em Barcarena (PA), nos anos 2000, e Mariana (MG), nos anos de 2010.

A primeira grande tragédia ambiental em decorrência do rejeito da mineração se deu na Amazônia, no âmbito da região de acumulação correspondente ao complexo bauxitaalumina-alumínio. Ao longo de dez anos nos anos 1980, a MRN depositou sistematicamente rejeito da lavagem da bauxita no lago Batata, em Oriximiná, soterrando mais de $30 \%$ da extensão do lago. A ação não era considerada ilegal ou sequer vista como problema ambiental. Foi, portanto, a opção "tecnológica" escolhida em detrimento da construção de barragem de rejeito. Nessa mesma década, aumentou o apelo pela questão ambiental e a pressão de ambientalistas nacionais e internacionais levou o governo e as empresas a adotarem outro modelo de descarte. A partir de 1989, como solução para mitigar o problema do rejeito, uma série de pequenas barragens justapostas foram sendo criadas no sítio da antiga mina de Saracá. Contudo, pouco se sabe sobre os riscos desse complexo de barragens, não existe nenhum estudo que aponte as particularidades dos seus impactos. Até hoje, denúncias de contaminação dos rios por populações do entorno seguem recorrentes e o lago Batata continua como problema não totalmente resolvido.

Também na região de acumulação do alumínio, em Barcarena (PA), a partir do ano 2000, têm sido frequentes as denúncias e os fatos comprovados de desastres ambientais. Vários deles noticiados pela mídia, como o extravasamento ocasional e a liberação de rejeito dessas barragens, provocando a contaminação do solo e das águas dos igarapés e do estuário do Rio Pará. Por conta da topografia plana (topo de baixos tabuleiros) e da proximidade do estuário, as barragens de Barcarena, uma vez extravasadas ou rompidas, alcançam rapidamente os cursos d’água, além de terem o risco ambiental aumentado, em virtude de entorno residencial densamente habitado.

Em Barcarena, os problemas socioambientais começaram com a poluição do ar causada por empresas mínero-industriais tanto da alumina-alumínio quanto do caulim. Como consequência disso, várias indivíduos foram atingidos e removidos da área onde funciona o Distrito Industrial de Barcarena, anteriormente áreas de colonização denominadas Murucupi 
e Montana, de início estimulada pela Albrás, para Vila do Conde ou para Curuperé ${ }^{16}$. Dessa última, a população foi então novamente removida no fim da década de 1990 e início da década de 2000 para Guajará da Serraria, ainda no município.

O Senhor Petrolino, durante o seminário Desastre da Mineração: Pará e Minas, realizado nos dias 25 e 26 de fevereiro de 2016 em Belém (PA), listou os "acidentes" ocorridos em Barcarena. O primeiro acidente de sua lista ocorreu em abril e maio de 2003 com o vazamento de lama vermelha de rejeito da Alunorte que contaminou o Rio Murucupi. O segundo aconteceu em junho de 2003, provocando a mortandade de peixes na praia de Itupanema, causada por carreamento de rejeitos da Alunorte. Em 2004, rejeitos da Imerys, mineradora de caulim, vazaram da sua barragem contaminando os igarapés Curuperê e Dendê. Em 2006 e 2007, novos vazamentos de polpa de minério do mineroduto e da barragem da Imerys resultaram na elaboração de um Termo de Ajuste e Contuda (TAC) com o Ministério Público do Pará. Em 2009, também em Barcarena, a lama vermelha que transbordou de um dos reservatórios da empresa causou danos ambientais ao Rio Murucupi e ao litoral onde o rio deságua. Essa lama vermelha, que contaminou a área, tinha na sua composição soda cáustica. Em consequência, o evento contaminou o ecossistema do rio, causando morte de peixes e fitoplânctons. Os pescadores de várias comunidades reclamaram, na ocasião, sobre os prejuízos no rio e no mar onde pescavam. A partir de então, quase que anualmente (2011, 2012, 2014 e 2016), rompimentos de minerodutos com efluentes ácidos e vazamentos de material das barragens de rejeito da Imerys impactaram, repetidamente, os igarapés e as comunidades da região. ${ }^{17}$

No contexto da região mínero-metalúrgica do Sudeste, em 2015, a mineradora brasileira Samarco S/A, empresa que extraí minério de ferro em Mariana (MG), esteve envolvida em um dos maiores desastres ambientais do setor mineral e do Brasil. No dia 5 de novembro do referido ano, rompeu-se a barragem de rejeito do Fundão, provocando uma enxurrada de lama e causando dezenove (19) mortes e danos na bacia do Rio Doce $(\mathrm{MG})^{18}$. Seguindo o curso do Rio Doce, afetou ainda as localidades de Bento Rodrigues, Paracatu de Baixo, em Mariana, e Gesteira e o núcleo urbano de Barra Longa. Depois de Mariana e Barra Longa, Governador Valadares, a capital regional, foi a cidade mais atingida, sofrendo com graves problemas de abastecimento e

${ }_{16}$ Barcarena tem sido também vítima de "acidentes" que envolvem a mineradora Imerys. Em 2004, houve uma nuvem de fuligem sobre Vila dos Cabanos. Em fevereiro de 2006, houve uma floração de algas na praia do Caripi e igarapé Murucupi, provocada pela composição química de efluentes lançados nas águas.

17 Barcarena, no entanto, sofreu com outros desastres ambientais: em 2000, como por exemplo, o naufrágio de balsa com derramamento de aproximadamente 2 milhões de litros de óleo BPF no Rio Pará, em 2002; derramamento de cerca de 100 quilos de coque (pó preto derivado do petróleo) no complexo industrial Albras/Alunorte, também no mesmo rio, em 2003. Em Vila do Conde foram registrados ainda: episódio de chuva de fuligem; mortandade de peixes no Rio Arienga próximo à área industrial da Cosipar, em 2007; vazamento de óleo das instalações da Petrobrás em 2008; naufrágio de rebocador provocando vazamento de aproximadamente 30 mil litros de óleo e uma mancha de cerca de 17 quilômetros de extensão em 2008, outra ocorrência de nuvem de fuligem; e em 2015, naufrágio de navio com 5 mil bois vivos, em 2010 (MPF, 2016).

18 O desastre de 2015 não foi, segundo informações da população de Mariana, o primeiro na história da Samarco em Minas Gerais outros vazamentos e rompimentos de barragens e dos dutos já haviam sido identificados pelos órgãos públicos e pela população atingida. 
caos social. No Espírito Santo, Linhares, Baixo Guandu e Colatina também foram duramente afetadas. Além dos danos causados aos diferentes grupos da região do Rio Doce - populações rurais, urbanas, litorâneas, pescadores, garimpeiros, indígenas, etc. -, o rompimento da barragem do Fundão causou fortes impactos sobre os ecossistemas fluviais, marinhos e costeiros, que se prolongaram por mais de $800 \mathrm{~km}$ de sua origem.

As regiões econômicas são criadas com a finalidade de acelerar os processos de acumulação. Elas são baseadas no projeto nacional desenvolvimentista de modernização voltado para a exploração mineral e suas transformações industriais - atualizado em distintos períodos. O Sudeste e Norte do país contém exemplos de regiões de acumulação que reúnem projetos sujeitos aos riscos tanto de perdas econômicos quanto ambientais. Um dos maiores problemas consiste em equilibrar as atenções às medidas de regulação dos riscos econômicos, com a importância atribuída às medidas de regulações ambientais, a fim de coibir comportamentos empresariais vorazes que aumentem os riscos aos ambientes e às sociedades locais ou que produzam desastres ambientais.

\section{CONSIDERAÇÕES FINAIS}

Não é demais frisar que não foi nossa intenção comparar desastres ambientais nem de detalhar os eventos selecionados. Mais uma vez, dois exemplos de ruptura ou vazamento de barragens de rejeitos de mineração foram utilizados para argumentar que esses não são casos únicos ou isolados. Foi também objetivo desse trabalho destacar o caráter geopolítico e geoeconômico das regiões econômicas criadas e discutir sobre os riscos gerados. Foi nosso propósito, principalmente, indagar as razões dos continuados desastres sócio-ambientais ocorridos, tais como o da Samarco e os de responsabilidade da Alunorte, os dois exemplos em regiões econômicas criadas pelo Estado em combinações com as empresas mineradoras e transformadoras minerais.

As regiões mínero-metalúrgicas nas quais os desastres ambientais ocorreram foram geradas na oportunidade de inserção das áreas ricas principalmente em minérios na economia mundo. A criação de regiões de acumulação capitalista faz nascer a necessidade de barragens, estradas, hidrelétricas, redes de telecomunicações e outras infraestruturas necessárias. Estão ligadas diretamente às funções exercidas pelas regiões de acumulação o papel crescente das cidades regionais (antigas e emergentes) nas redes globais. As regiões econômicas, portanto, fazem parte do processo econômico da estruturação de espaços e dos projetos políticos de desenvolvimento, que implicam na construção de unidades espaciais objetivando viabilização de "novos" espaços de acumulação capitalista, cada vez 
mais globais. Tais regiões econômicas têm, portanto, origens em estratégias geopolíticas ou geoeconomias, como tantos outros casos no Brasil e no mundo. Os riscos ambientais pairam e continuam a pairar sobre essas regiões econômicas mínero-metalúrgicas, como é o caso de Carajás, Oriximiná/Juruti, Ipixuna/Paragominas e Barcarena, no Pará, ou do Quadrilátero Ferrífero, em Minas Gerais, onde os riscos existem e continuarão a existir, requerendo regulações e monitoramentos constantes, públicos e eficientes.

Nos países periféricos, a construção de escalas regionais tenderá a envolver a produção (ou reprodução) de "novos" espaços econômicos estratégicos por suas riquezas em matériasprimas. As regiões mineiras ou mínero-metalúrgicas reúnem diversidades de projetos econômicos, todos envolvendo riscos ambientais. A Samarco, a Mineração Rio do Norte ou a Alunorte não são projetos únicos em suas respectivas regiões. No caso do Norte, registros de danos ambientais são também atribuídos à Imerys e à Cosipar, presentes em Barcarena.

Para resumir, reforçamos o fato de que as regiões (corredores de minérios) econômicas ou de acumulações capitalistas produzem concomitantemente "regiões de riscos ambientais". Além do mais, no caso do Norte brasileiro, menos do que no Sudeste, as regiões, no entanto, não dispõem ainda de relações regionais coesas, refletindo o não desenvolvimento regional autossustentado. Pelo tempo de implantação desses projetos de desenvolvimento, quase meio século, esperávamos já maiores integrações internas (solidariedades ou trocas) entre cidades ao longo de uma mesma região ou entre regiões (corredores), o que repercutiria em uma base econômica mais pujante. Nesse modelo apenas algumas cidades - portuárias, mineradoras ou capitais - apresentam dinâmicas industriais e de negócio ou de serviços mais significativas, mesmo assim muito dependente de uma só atividade econômica.

Unidades espaciais que possuem o extrativismo industrial e a transformação mineral como motores do desenvolvimento possuem riscos ambientais associados, que podem resultar em desastres incalculáveis se não existirem regulações mais rigorosas sobre as ações econômicas e seus efeitos ambientais. Caso contrário, nada nos faz acreditar que o modelo de desenvolvimento voltado para (re) criação de regiões de acumulação e as regulações ambientais vigentes impedirão a ocorrência de novos desastres ambientais.

Finalmente, não devemos esquecer que as extrações minerais e as transformações minerais não são atividades de muita longa duração no espaço ou no tempo, porém, os riscos oferecidos por barragens, minas e outras infraestruturas abandonadas tendem a ultrapassar o ciclo de vida da exploração mineral. No período áureo da mineração, os municípios foram ou ainda poderão ser temporariamente fortalecidos, modificando as malhas municipais. Isso porque os arranjos municipais são politicamente criados e os papéis 
das cidades, por sua vez, alteram-se ou redefinem-se de acordo com o comportamento do capital. Todavia, para alcançar o desenvolvimento autossustentado é necessário que os governos nacional, regionais e municipais mudem o modelo fundamentado na criação de regiões acumulativas vigente, multiplicando e diversificando suas bases produtivas. Não se pode esquecer, a necessidade de engajamento da sociedade (particularmente, dos grupos atingidos). Os diálogos entre sociedade, governos e empresas são imprescindíveis.

\section{REFERÊNCIAS:}

1. BANINGER, R.; CUNHA, J. M.; CARMO, R. L. (Orgs) Migração e ambiente nas aglomerações urbanas. Campinas: NEPO/UNICAMP, 2001 pp. 395-418.

2. BECK, U. (2010). Sociedade de Risco. Rumo a uma outra modernidade. (Tradução de Sebastião Nascimento). São Paulo: Editora 34, 2010.

3. BOWKER, L. N.; CHAMBERS, D. M. The Risk, Public Liability \& Economics of Tailings Storage Facility Failures. Research paper. Stonington, ME, 2015.

4. BRÜSEKE, F. J.. Risco Social, risco ambiental, risco individual. Ambiente \& Sociedade. Campinas, v.1, 1997. pp. 117-134.

5. BUNKER, S.. Underdevelopment the Amazon. Chicago /Londres: University of Chicago Press, 1985.

6. BUNKER, S. e CICCANTELL, P.. Globalization and the Race for Resources. Baltimore: The Johns Hopkins University Press, 2005.

7. COElHO, M. C.; MONTEIRO, M.; BARBOZA, E. Geografia da Mineração em Mutações: fronteiras de commodities minerais, corredores de exportações e cidades. Território (UFRJ), v. 16, p. 53-83, 2012.

8. COX, K. R. Space of dependence, space of engagement and the politics of scale, or: looking for local politics. Political Geography, 17, 1998. pp. 1-23.

9. DAVIES, M.; MARTIN, T. Mining Market Cycles and Tailings Dam Incidents. In: 13th International Conference on Tailings and Mine Waste, Bana, AB, 2009.

10. EGLER, C.; PIRES DO RIO, G.. Geoeconomia do Gás no Cone Sul. Relatório de Pesquisa. Processo: no. 26.2828/00.0 Coordenação de C. Egler Internet, 2003.

11. GEIGER, P.; CORRÊA, R.. De Vitória a Belo Horizonte pelo Vale do Rio Doce. União Geográfica Internacional. Livro-Guia da viagem de estudos realizados por ocasião do Colóquio Sobre Desigualdades Regionais do Desenvolvimento, Vitória ES - Abril de 1971.

12. GIDDENS, A. A Constituição da Sociedade. (Tradução de Álvaro Cabral) São Paulo: Martins Fontes, 2013. 
13. GIDDENS, A. Mundo em Descontrole, o que a globalização está fazendo de nós. Rio de Janeiro e São Paulo: Editora Record, 2000.

14. HARVEY, D. Justice, Nature \& the Geography of Difference. Oxford: BLACKWELL, 1996.

15. HOGAN, D.; MARANDOLA, E.. Natural Hazards: O Estudo Geográfico dos Riscos e Perigos. Ambiente \& Sociedade, vol. 7, no 2. Campinas em Julho/Dez. 2004.

16. HOGAN, D., CUNHA, J.; OLIVEIRA, A. ; CARMO, R.. Urbanização e vulnerabilidade sócio ambiental: o caso de Campinas. Campinas: NEPO/UNICAMP, 2001.

17. MPF - Ministério Público Federal. Ministério Público pede fornecimento urgente de água potável à população de Barcarena (PA). 28/10/2016. Disponível em http://racismoambiental.net. br/2016/10/28/ministerio-publico-pede-fornecimento-urgente-de-agua-potavel-a-populacaode-barcarena-pa/. Acessado em 15/12/2016.

18. SANTOS, R.; WANDERLEY, L. Dependência de barragem, alternativas tecnológicas e a inação do Estado: repercussões sobre o monitoramento de barragens e o licenciamento do Fundão. In: Zonta, M; Trocate, C. A Questão Mineral no Brasil - vol. 2: Antes fosse mais leve a carga: reflexões sobre o desastre da Samarco/ Vale / BHP Billiton. Marabá-PA: Iguana. 2016. pp. 87-139.

19. SANDRONI, P. Dicionário de Economia do Século XXI. Rio de Janeiro e São Paulo: Editora Record, 2007.

20. SMITH, N. "Scale Bending and the Fate of the National'. In: Sherppar, E McMaster, Robert B (Ed) Scale \& Geographic Inquiry Nature, Society, Method. Malden MA (EUA), Oxford: Blackwell, 2004. pp. 192-212.

21. STRAUCH, Ney. A Bacia do Rio Doce. Estudo Geográfico. Rio de Janeiro: IBGE, 1955.

22. SWYNGEDOUW, E. "Scaled Geographies: Nature, Place, and the Politic of Scale”. In: Sherppard, E. e McMaster, Robert B (Ed) Scale \& Geographic Inquiry Nature, Society, Method. Malden MA (EUA), Oxford: Blackwell, 2004. pp. 129-212.

23. ZHOURI, A. et al. O desastre de Mariana: colonialidade e sofrimento social. In: ZHOURI, A.; BOLADOS, P.; CASTRO, E. (Orgs.) Mineração na América do Sul, Neoextrativismo e Lutas Territoriais, Editora Annablume, 2016. pp. 45-66.

ARTIGO RECEBIDO EM DEZEMBRO DE 2016

ARTIGO ACEITO EM MARÇO 2017 